\title{
Penerapan Metode Peer Tutoring Untuk Meningkatkan Pemahaman Konsep Materi Perkalian Bersusun Pada Siswa Kelas III SD
}

\author{
Jhon Tetiwar, Oce Datu Appulembang \\ oce.appulembang@uph.edu \\ Universitas Pelita Harapan
}

\begin{abstract}
The Implementation Of Peer Tutoring Method To Improve Conceptual Understanding On Multiple Multiplication Material For Grade Iii B Students In Sdn Inpres Harapan
\end{abstract}

\begin{abstract}
In learning Mathematics, conceptual understanding is a primary competency that the students must acquire, because through understanding the concept the students would understand what is being learned and are able to apply them thus they can pursue toward the next materials. However, in the reality of a learning process, the students have not yet understood the concept correctly. Therefore, the researcher tried to implement the peer tutoring method. Thus this research is aimed to know that the implementation of peer tutoring method can improve the conceptual understanding on multiple multiplication of the grade III $B$ students in SDN Inpres Harapan. The research method used in this research was Classroom Action Research methodology (CAR) of Kemmis and Taggart spiral model. This research was conducted upon the students of grade III B in SDN Inpres Harapan on August 2017 until October 2017 within three cycles. Instruments used in this research were teacher mentor observation sheet, teacher mentor and peer teacher interview sheet, students' questionnaire, as well as students' comprehension test sheet. Based on the research result, it can be concluded that the implementation of peer tutoring method can improve the conceptual understanding on multiple multiplication of the grade III B students in SDN Inpres Harapan.
\end{abstract}

Keywords: peer tutoring method, conceptual understanding

Received date: 12 Juli 2018

Article Info

Revised date: 27 Agustus 2018 Accepted date: 21 September 2018

\section{PENDAHULUAN}

Pendidikan adalah proses seumur hidup yang dapat terjadi di dalam berbagai konteks dan keadaan yang tidak terbatas (Knight, 2009 hal. 16). Van Brummelen (2009, hal.19) menyampaikan bahwa pendidikan Kristen bertujuan untuk membantu dan membimbing para siswa menjadi murid Yesus Kristus yang bertanggung jawab. Seorang guru Kristen harus membantu siswa untuk mengembangkan setiap bakat unik dan kemampuan yang mereka miliki untuk menghasilkan sesuatu yang berarti secara pribadi (Van Brummelen, 2009. hal. 22). Salah satu bakat unik dan kemampuan yang harus dikembangkan adalah kemampuan berpikir (kognitif) siswa.

Berbicara mengenai kemampuan terkhususnya siswa kelas III SD yang mana berada pada tahap operasional konkret, anak-anak sudah memiliki intelegensi yang merupakan proses pembentukan pemahaman yang mana anak-anak sudah memiliki kemampuan untuk memahami aspek-aspek kumulatif, memahami cara mengombinasikan dan kemampuan untuk mengelompokkan (Piaget (dalam Syah, 2014, hal. 70). Johnson \& Medinnus (dalam Desmita 2012, hal. 156) juga menyampaikan bahwa pada masa ini anak sudah mengembangkan pikiran logis, mulai mampu memahami operasi dalam sejumlah konsep, seperti 5 × $6=30 ; 30: 6=5$ dan mengandalkan logika untuk memahami alam sekitar.

Berdasarkan teori diatas, maka siswa kelas 3 SD seharusnya sudah memiliki pemahaman konsep yang baik, salah satunya dalam pembelajaran matematika dengan materi perkalian bersusun pendek. Materi tersebut sesuai dengan kurikulum 2013 dengan Kompetensi Dasar (KD) yang digunakan ialah menyatakan suatu bilangan sebagai jumlah, selisih, hasil kali, atau hasil bagi dua bilangan cacah. KD tersebut menuntut siswa untuk memiliki pemahaman konsep agar mereka dapat menyatakan suatu bilangan sebagai hasil kali, bagi, jumlah dan selisih. 
Berdasarkan hasil observasi dan mengajar di kelas III B pada SDN Inpres Harapan, ditemukan bahwa ketika siswa diminta untuk menjelaskan ulang langkah pengerjaan soal, para siswa belum mampu menjelaskan dengan benar. Selain itu, pada akhir pembelajaran peneliti memberikan tes kepada siswa tingkat kesulitan soal sampai pada level pemahaman. Hasil yang didapat dari 25 orang siswa, hanya 7 orang (28\%) yang mencapai Kriteria Ketuntasan Minimal (KKM) yakni 62 (lihat Lampiran A-4). Berdasarkan fakta tersebut, maka yang menjadi masalah adalah pemahaman konsep siswa akan materi yang telah diajarkan.

Menurut Slameto (2010, hal. 65) agar siswa dapat belajar dengan baik, maka metode mengajar harus diusahakan dengan tepat, efisien, dan efektif. Oleh sebab itu dalam upaya meningkatkan pemahaman konsep siswa, peneliti menerapkan metode peer tutoring. Penelitian sebelumnya pernah dilakukan oleh Hakim, Akhdinirwanto dan Ashari (2013) menggunakan metode demonstrasi oleh tutor sebaya untuk meningkatkan pemahaman konsep IPA siswa kelas VII yang hasilnya menunjukkan bahwa dapat meningkatkan pemahaman konsep siswa. Peneliti memilih menggunakan metode ini dikarenakan sesuai dengan kebutuhan, dan karakteristik siswa di dalam kelas yaitu senang belajar secara berkelompok dan bertanya kepada temannya dibanding bertanya kepada guru.

Melalui pembelajaran menggunakan metode peer tutoring, siswa akan belajar dengan mendapatkan bantuan dan bimbingan dari teman yang pandai, yang berperan sebagai tutor. Hal tersebut sesuai dengan pendapat Piaget (dalam Sani 2013, hal. 11) bahwa pengetahuan dibentuk berdasarkan interaksi antara individu dengan lingkungan, dan dalam proses belajar mengutamakan interaksi dalam kelompok sebaya. Maka dalam pembelajaran dengan metode peer tutoring siswa akan lebih mudah memahami konsep karena terjadi interaksi di dalam kelompok sebaya dengan menggunakan bahasa yang lebih sederhana untuk dipahami. Melalui metode peer tutoring ini siswa dapat saling mengasihi, yang mana mereka saling mengajarkan, menghargai dan mendengarkan. Oleh sebab itu, di sinilah letak peran seorang guru Kristen dalam pembelajaran. Sebagaimana yang disampaikan oleh Van Brummelen (2009, hal. 60-61) yaitu menjadikan kelas sebagai komunitas yang saling menyatakan kasih dan membantu siswa untuk menemukan diri mereka sebagai gambar dan rupa Allah yang telah ditebus

\section{KAJIAN PUSTAKA}

\section{Metode Peer Tutoring}

Menurut Sani (2013, hal. 198-199), metode peer tutoring adalah sebuah metode yang menuntut peserta didik untuk aktif berdiskusi dengan sesama temannya, atau mengerjakan tugas kelompok dengan bimbingan atau arahan teman yang kompeten. Senada dengan pendapat tersebut, Sanubari, Yamitnah dan Redjeki (2014, hal. 147) mengemukakan bahwa metode tutor teman sebaya merupakan metode yang melibatkan siswa yang memiliki kemampuan di atas rata-rata untuk membantu siswa yang lain dalam memahami materi pelajaran. Indrianie (2015, hal. 128) juga menyampaikan bahwa pembelajaran tutor sebaya adalah bagaimana mengoptimalkan kemampuan peserta didik yang berprestasi dalam satu kelas untuk mengajarkan atau menularkan kepada teman sebaya mereka yang kurang berprestasi, sehingga peserta didik yang kurang berprestasi bisa mengatasi ketertinggalannya.

Berdasarkan beberapa pendapat di atas maka dapat disimpulkan bahwa metode peer tutoring adalah metode pembelajaran yang melibatkan seluruh siswa di dalam kelompok secara aktif untuk berdiskusi, saling mengajarkan, dan mendengarkan arahan atau bimbingan dari siswa yang pandai sebagai tutor.

\section{Langkah-langkah Penerapan Metode Peer Tutoring}

Sani (2013, hal. 201) membagi tahapan penerapan metode peer tutoring menjadi beberapa tahap, yakni sebagai berikut: 1) Guru menyusun kelompok belajar yang beranggotakan 3 atau 4 orang dengan kemampuan beragam dan setiap kelompok minimal memiliki satu orang peserta didik yang memiliki kemampuan tinggi untuk menjadi tutor teman sejawat; 2) Guru menjelaskan tentang cara penyelesaian tugas melalui belajar kelompok dengan metode peer teaching dan peran dari setiap anggota kelompok; 3) Guru menjelaskan materi pembelajaran kepada semua siswa dan memberi peluang tanya jawab apabila terdapat materi yang belum jelas; 4) Guru memberikan tugas dengan 
catatan peserta didik yang kesulitan dalam mengerjakan tugas dapat meminta bimbingan kepada teman yang ditunjukkan sebagai tutor atau guru; 5) Guru mengamati aktivitas belajar dan memberi penilaian kompetensi; 6) Guru, tutor dan peserta didik memberikan evaluasi proses belajar mengajar menetapkan tindakan lanjut kegiatan putaran berikutnya.

Gordon (2005, hal. 7) juga menyebutkan 5 langkah yang harus dilakukan dalam menerapkan metode peer tutoring: 1) Selecting the tutoring partners and program goals; 2) Designing the tutoring curriculum; 3) Tutor training; 4) Monitoring the program; 5) Evaluation. Anas (2014, hal. 69) juga menjelaskan beberapa tahapan penerapan metode peer tutoring antara lain: 1) Merancang perlakuan; 2) Menentukan tutor; 3) Pelatihan kepada tutor yang dilakukan di dalam maupun di luar jam pelajaran, namun guru juga harus tetap menyampaikan materi kepada semua siswa; 4) Melaksanakan, siswa (tutee) dan tutor belajar bersama yang mana tutor memberi penjelasan dan membantu menyelesaikan tugas dari guru; 5) Melakukan evaluasi, yang diawali dengan monitoring kemudian evaluasi secara continue, untuk mengetahui kesulitan-kesulitan yang dihadapi tutor maupun tutee selama berjalannya proses pembelajaran.

Berdasarkan pendapat para ahli, maka dapat disimpulkan langkah-langkah penerapan metode peer tutoring yang juga digunakan peneliti dalam penelitian ini, yakni sebagai berikut: 1) Guru memilih dan menentukan tutor berdasarkan nilai akademik siswa yang tinggi; 2) Guru menyampaikan materi pembelajaran kepada semua siswa; 3) Guru memberikan pelatihan bagi siswa yang menjadi tutor; 4) Guru membagi siswa dalam kelompok yang heterogen dengan jumlah 3-4 orang. Setiap kelompok memiliki satu orang tutor; 5) Guru menjelaskan peran tutor dan tutee di dalam kelompok; 6) Guru memberikan tugas kepada setiap kelompok; 7) Guru meminta tutor untuk membimbing tutee (teman) yang mengalami kesulitan; 8) Guru melakukan pemantauan dan membantu kelompok atau tutor yang kesulitan dalam membimbing; 9) Guru memberikan tes kepada siswa yang dikerjakan secara individu; 10) Guru memberikan kesimpulan.

\section{Pemahaman Konsep}

Pemahaman konsep merupakan suatu kemampuan yang menjadi dasar bagi siswa dalam mengerjakan matematika (Annajmi, 2016, hal. 2). Senada dengan hal tersebut, Kilpatrick, Swafford \& Findell dalam Afrilianto (2012, hal. 193) menyampaikan bahwa pemahaman konsep (conceptual understanding) adalah kemampuan dalam memahami konsep, operasi dan relasi dalam matematika. Sedangkan menurut Widyastuti (2015, hal. 52) pemahaman konsep diartikan sebagai penyerapan arti suatu materi bahan yang dipelajari. Maka siswa dinyatakan telah memahami sebuah konsep apabila siswa mampu menyampaikan dan menjelaskan kembali konsep yang diajarkan menggunakan kalimat sendiri dan bukan menghafal (Ginanjar \& Kusmawati, 2016, hal. 266). Senada dengan hal tersebut, Annajmi (2016, hal. 2) juga menambahkan bahwa seorang siswa memiliki pemahaman konsep yang baik apabila mampu menjelaskan kembali konsep yang telah dipelajari, memberikan contoh dan bukan contoh dari konsep serta menggunakan konsep dalam pemecahan masalah.

Berdasarkan penjelasan para ahli, dapat disimpulkan bahwa pemahaman konsep adalah kemampuan dasar dalam mengartikan suatu konsep yaitu jika dapat menjelaskan ulang konsep yang telah diterima dengan menggunakan kalimat yang dapat dimengerti serta dapat memecahkan masalah berkaitan dengan konsep tersebut dan mengaitkan dengan konsep yang lainnya. Pemahaman konsep matematika pada materi perkalian bersusun sesuai dengan Kompetensi Dasar (KD) yaitu menyatakan suatu bilangan sebagai jumlah, selisih, hasil kali, atau hasil bagi dua bilangan cacah. Maka indikator pemahaman konsep yang harus dimiliki siswa adalah 1) Siswa mampu menjabarkan langkah-langkah operasi perkalian bersusun pendek dengan teknik menyimpan; 2) Siswa mampu menghitung hasil operasi perkalian bersusun pendek dengan teknik menyimpan

\section{METODE PENELITIAN}

Metode penelitian yang digunakan adalah Penelitian Tindakan Kelas (PTK). Menurut Arikunto, Suhardjono \& Supardi, penelitian tindakan kelas adalah penelitian yang dilakukan oleh guru dengan tujuan memperbaiki mutu praktik pembelajaran dikelasnya (2015, hal. 124). Peneliti akan menerapkan PTK model sprila dari Kemmis dan Taggart. Model penelitian ini terdiri atas empat tahapan, yaitu: perencanaan (planing), pelaksanaan tindakan (acting), observasi (observation), dan refleksi (reflection) (Komara, 2012). 
Penelitian dilakukan di sekolah SDN Inpres Harapan-Sentani pada kelas III B dengan jumlah 25 orang siswa yang memiliki kemampuan heterogen. Penelitian ini berlangsung dari bulan Agustus 2017 sampai Oktober 2017 dengan jumlah siklus sebanyak tiga kali. Instrumen yang digunakan untuk mengukur keterlaksanaan penerapan metode peer tutoring adalah lembar observasi guru mentor, lembar wawancara guru mentor dan teman sejawat serta lembar angket siswa. Untuk mengukur tingkat pemahaman konsep siswa, peneliti menggunakan lembar tes pemahaman siswa.

\section{HASIL PENELITIAN DAN PEMBAHASAN}

Berdasarkan data valid yang didapat dari hasil triangulasi terhadap ketiga instrumen, yakni hasil observasi guru mentor, hasil wawancara guru mentor dan teman sejawat serta angket siswa dapat dilihat tingkat keterlaksanaan penerapan metode peer tutoring yang disajikan pada gambar diagram berikut ini:

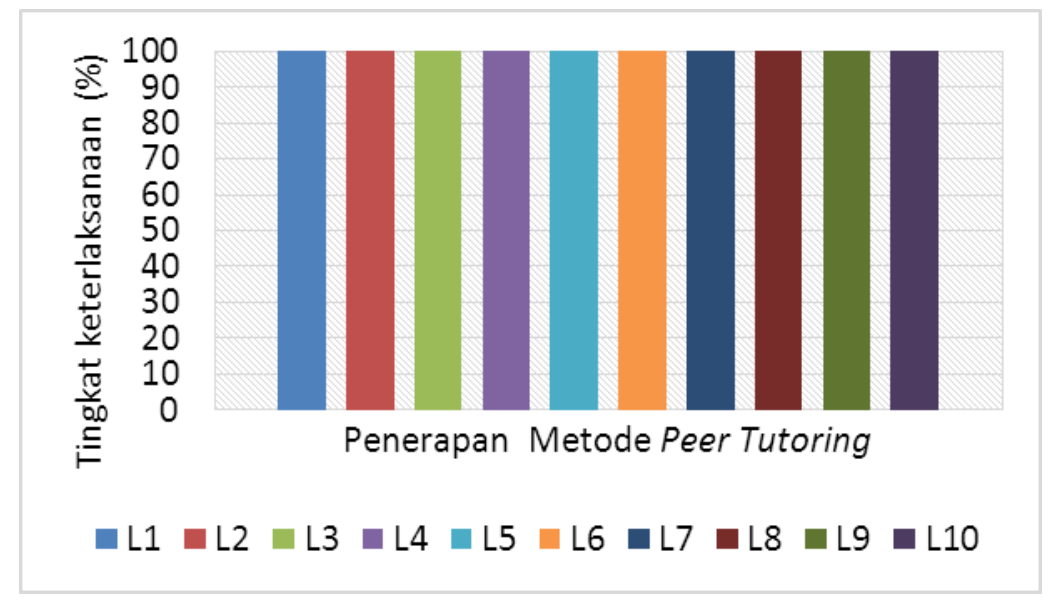

Gambar 1.

Diagram Persentase Keterlaksanaan Metode Peer Tutoring

Diagram di atas menunjukkan bahwa tingkat keterlaksanaan mencapai 100\% yang artinya penerapan metode peer tutoring sudah terlaksana.

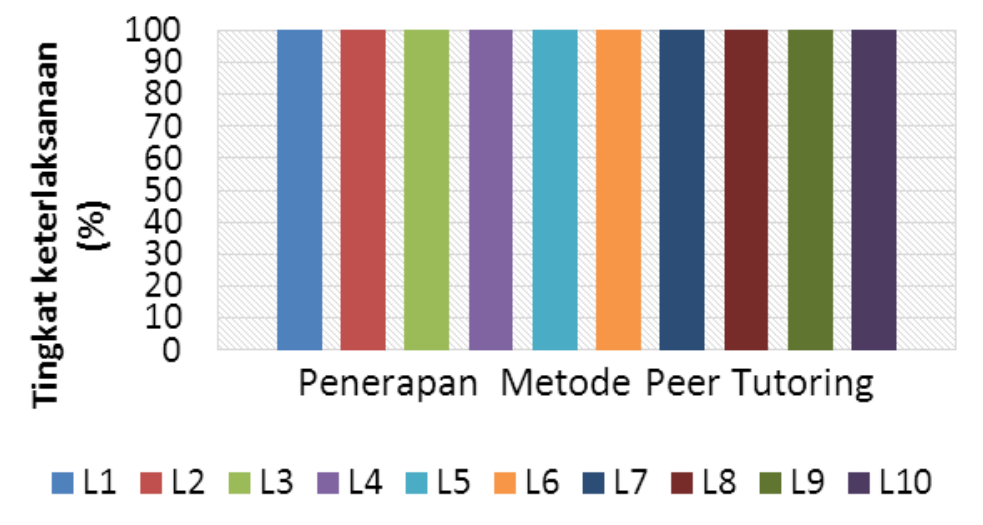

Gambar 2.

Diagram Persentase Keterlaksanaan Metode Peer Tutoring pada Siklus II

Melalui gambar 2, menunjukkan bahwa pada siklus II metode peer tutoring sudah terlaksana. Keterlaksanaan penerapan metode peer tutoring ini juga mampu dipertahankan pada siklus III yang disajikan pada gambar diagram berikut ini: 


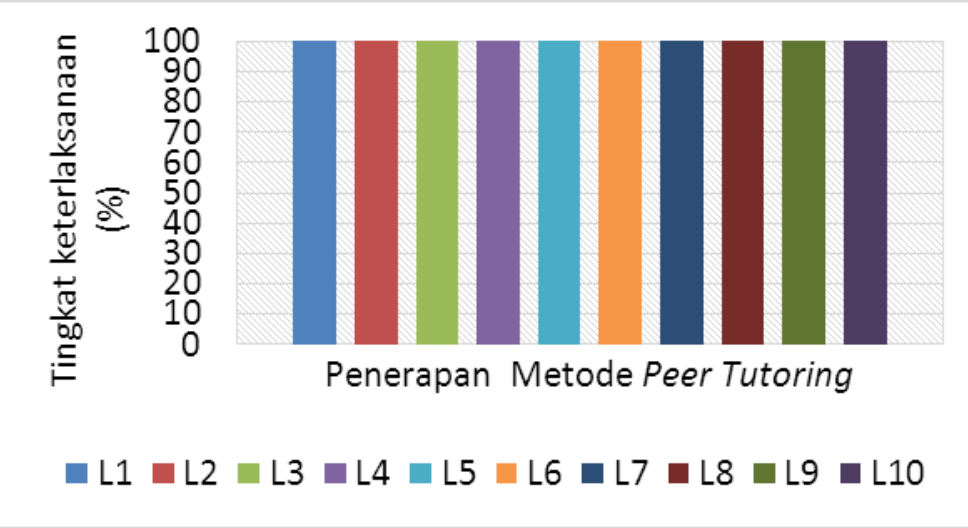

Gambar 3.

Diagram Persentase Keterlaksanaan Metode Peer Tutoring pada Siklus III

Melalui penyajian ketiga diagram di atas, terlihat bahwa penerapan metode peer tutoring sudah terlaksana dari siklus I sampai siklus III artinya setiap langkah pada metode tersebut dilaksanakan. Ditegaskan pula berdasarkan hasil wawancara guru mentor dan teman sejawat, peneliti dalam menerapkan metode peer tutoring di siklus II dan siklus III lebih maksimal dari siklus sebelumnya. Pencapaian ini tentu berdampak pada pencapaian ketuntasan setiap indikator pemahaman konsep siswa dari siswa dari siklus I sampai siklus III. Pencapaian ketuntasan setiap indikator pemahaman konsep disajikan pada gambar diagram berikut ini:

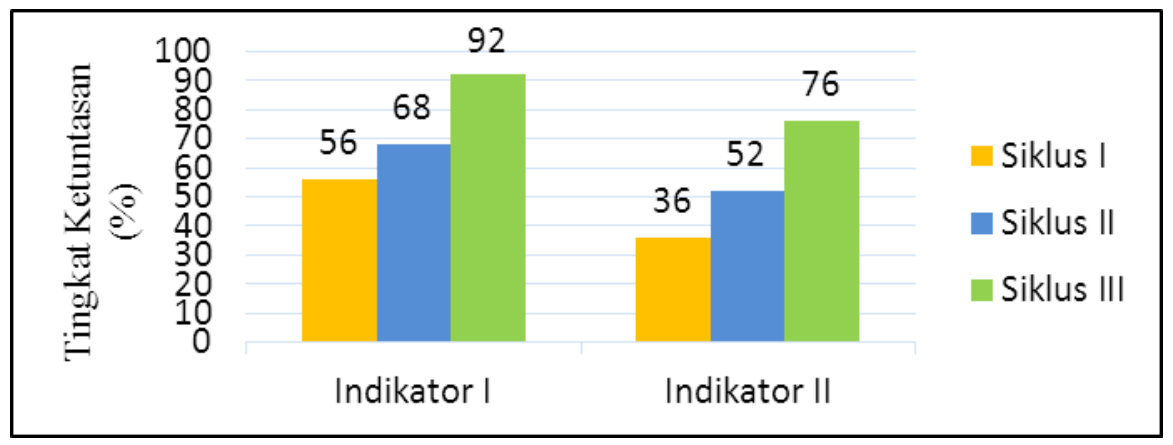

Gambar 4.

Diagram Pencapaian Ketuntasan Setiap Indikator pada Siklus I, Siklus II dan Siklus III

Berdasarkan penyajian data di atas, terlihat bahwa pencapaian ketuntasan siswa pada setiap indikator pemahaman konsep mengalami peningkatan, yakni: Indikator I pada siklus I mencapai 56\% dari 25 siswa, siklus II mencapai 68\% dan siklus III mencapai 92\%. Indikator II pada siklus I, persentase jumlah siswa yang tuntas sebesar 36\%, siklus II mencapai 52\% dan siklus III mencapai $76 \%$.

Meningkatnya pemahaman konsep siswa disebabkan oleh beberapa faktor yang dilakukan pada setiap tahapan metode peer tutoring. Salah satunya adalah pada langkah ke-7 yaitu guru meminta tutor untuk membimbing tutee (teman) yang mengalami kesulitan, peneliti berulang-ulang meminta tutor untuk membimbing tutee. Sebagai hasilnya, tutor semakin lebih baik dalam menjalankan perannya di dalam kelompok yakni membimbing dan membantu tutee untuk memahami konsep. Hal ini tentu sesuai dengan apa yang disampaikan oleh Vasay (dalam Abdelkarim \& Abuiyada, 2016) bahwa kelebihan metode peer tutoring adalah siswa yang pintar akan menguasai konsep, sedangkan bagi siswa yang lamban dapat memperbaiki dan mengembangkan pemahaman mereka.

Peneliti juga sudah berusaha untuk membimbing secara berulang-ulang kelompok yang kesulitan ketika mengerjakan soal latihan. Hal ini bertujuan untuk mengatasi kebingungan yang dialami oleh kelompok tersebut atau tutor yang mengajari. Siswa juga diberikan kesempatan untuk membaca tabel perkalian di dalam proses pembelajaran sehingga dapat memperkuat ingatan mereka akan hasil perkalian bilangan satu angka yang menjadi syarat sebelum masuk dalam materi perkalian 
bersusun. Hal tersebut senada dengan pendapat Sani (2013, hal. 11) bahwa diperlukan pengetahuan prasyarat yang dapat dikaitkan dengan pengetahuan baru dalam upaya memudahkan peserta didik memahami konsep. Selanjutnya kondisi kelas yang semakin nyaman bagi siswa untuk belajar melalui interaksi.

Terjadinya interaksi antar tutor dan para tutee di dalam kelompok dari siklus ke siklus sehingga dapat memperbaiki kualitas belajar siswa di dalam kelompok. Setiap tutor berusaha untuk memahami terlebih dulu materinya agar dapat membimbing tutee atau teman kelompoknya dengan baik. Hal ini tentunya membuat para tutor semakin mengerti karena menggali lebih lagi sebelum mengajarkannya. Penelitia juga berusaha untuk menentukan setiap anggota kelompok dengan tepat, yang mana memperhatikan tingkat kenyamanan siswa di dalam kelompok. Semakin baiknya kualitas belajar di dalam kelompok sebaya dapat mempengaruhi peningkatan pemahaman konsep siswa karena terjadinya interaksi yang baik di dalam kelompok. Sebagaimana yang disampaikan oleh Piaget (dalam Sani, 2013) bahwa pengetahuan dibentuk berdasarkan interaksi antara individu dengan lingkungan dan dalam proses belajar mengutamakan interaksi dalam kelompok sebaya, buka interaksi dengan orang yang lebih dewasa. Melalui interaksi antara siswa di dalam kelompok, siswa akan lebih mudah memahami bahasa teman sebaya karena menggunakan bahasa yang sederhana sehingga mereka dapat memahami konsep dengan tepat.

Berdasarkan hal tersebut, ketika seorang siswa belajar, mereka seharusnya menerima informasi sesuai dengan kemampuan mereka untuk memahami informasi. Melalui belajar bersama teman sebaya, dapat meningkatkan pemahaman konsep siswa yang diajarkan menggunakan bahasa yang dapat dengan mudah dimengerti oleh mereka. Oleh sebab itu guru harus memfasilitasi siswa untuk melakukan interaksi dalam proses belajar. Sanjaya (2009, hal. 198) juga menyampaikan bahwa guru perlu mengarahkan siswa bisa mengembangkan kemampuan berpikirnya melalui interaksi mereka. Akan tetapi dalam pembelajaran guru harus berperan lebih dari seorang fasilitator yang hanya memfasilitasi siswa melainkan membimbing siswa untuk melayani Tuhan dengan cara mau mendengarkan dan bertanggung jawab (Van Brummelen, 2009, hal. 34-35). Hal tersebut terlihat melalui pembelajaran menggunakan metode peer tutoring.

\section{SIMPULAN DAN SARAN}

Berdasarkan hasil penelitian maka dapat disimpulkan bahwa penerapan metode peer tutoring dapat meningkatkan pemahaman konsep materi perkalian bersusun pendek pada siswa kelas III B di SDN Inpres Harapan. Peningkatan pencapaian ketuntasan pemahaman konsep terlihat pada pencapaian ketuntasan siswa terhadap setiap indikator pemahaman konsep. Indikator I pada siklus I mencapai 56\%, kemudian 68\% di siklus II dan mencapai 92\% pada siklus III. Indikator II mencapai $36 \%$ pada siklus I, kemudian di siklus II 52\% dan pada siklus III mencapai 76\%.

Saran dari penelitian ini adalah agar dalam pelaksanaan peer tutoring, dapat dikembangkan lagi mengenai bimbingan terhadap tutor dengan memberikan petunjuk yang tepat mengenai tugas dan tanggugn jawab mereka. Dalam penerapan metode ini, hubungan antar siswa perlu dipertimbangkan agar dapat lebih maksimal dalam pelaksanaannya.

\section{UCAPAN TERIMAKASIH}

Terimakasih kepada pihak SD Kampung Harapan atas kesempatan yang diberikan kepada peneliti untuk tugas belajar lapangannya sekaligus melakukan penelitian ini. Terimakasih kepada pihak Teachers College UPH yang telah memberikan kesempatan internship di sekolah ini.

\section{DAFTAR PUSTAKA}

Abdelkarim, R., \& Abuiyada, R. (2016). The Effect of Peer Teaching on Mathematics Academic Achievement of The Undergraduate Students in Oman. Internasional education studies. IX(5), 124-132.

Afrilianto, M. (2012). Peningkatan Pemahaman Konsep dan Kompetensi Stategis Matematis Siswa SMP dengan Pendekatan Metaphorical Thinking. Jurnal infinity. I(2). 192-202.

Anas, M. (2014). Mengenal Metode Pembelajaran. Pasuruan: CV. Pustaka Hulwa 
Penerapan Metode Peer Tutoring Untuk Meningkatkan Pemahaman Konsep Materi Perkalian

Bersusun Pada Siswa Kelas III SD (Jhon Tetiwar, Oce Datu Appulembang)

Annajmi. (2016). Peningkatan Kemampuan Pemahaman Konsep Matematik Siswa SMP Melalui Metode Penemuan Terbimbing Berbantuan Sofware Geogebra. Journal Of Mathematics Education And Science. II(1), 1-10.

Arikunto, S., Suhardjono, \& Supardi. (2015). Penelitian Tindakan Kelas: Edisi Revisi. Jakarta: Bumi Aksara.

Ginanjar, G., \& Kusmawati, L. (2016). Peningkatan Kemampuan Pemahaman Konsep Perkalian Melalui Pendekatan Pembelajaran Konstruktivisme Pembelajaran Matematika di Kelas 3 SDN Cibaduyut 4. Jurnal pendidikan guru sekolah dasar, I(2), 262-271.

Gordon, E., E. (2005). Peer Tutoring: A Teacher's Resource Guide. Toronto: ScarecrowEducation

Hakim, K. Akhdinirwanto, R., W., \& Ashari. (2013). Penerapan Metode Demonstrasi oleh Tutor Teman Sebaya untuk Peningkatan Pemahaman Konsep IPA Siswa Kelas VII SMP Negeri 9 Purwerejo Tahun Pelajaran 2012/2013. Radiasi, III(2), 174-177.

Indrianie, N., S. (2015). Penerapan Model Tutor Sebaya pada Mata Pelajaran Bahasa Inggris Reported Speech terhadap Hasil Belajar Peserta Didik MAN Kota Probolinggo. Jurnal kebijakan dan pengembangan pendidikan, I(1), 126-132.

Knight, G. R. (2009). Filsafat dan Pendidikan: Sebuah Pendahuluan dari Perspektif Kristen. Jakarta: Universitas Pelita Harapan.

Komara, E. (2012). Penelitian Tindakan Kelas Dan Peningkatan Profesionalitas Guru. Bandung: PT Refika Aditama

Sani., R. A. (2013). Inovasi Pembelajaran. Jakarta: Bumi Aksara

Sanjaya, W. (2009). Strategi Pembelajaran: Berorientasi Standar Proses Pendidikan. Jakarta: Kencana.

Sanubari, F., Yamitnah, S., \& Redjeki, T. (2014). Penerapan Metode Pembelajaran Tutor Teman Sebaya Dilengkapi dengan Media Interaktif Flash untuk Meningkatkan Minat dan Prestasi Belajar Siswa Kelas XI IPA SMA Negeri 1 Sukoharjo Tahun Pembelajaran 2013/2014 Pada Materi Larutan Penyangga. Jurnal pendidikan kimia, III(4), 145-154.

Slameto. (2010). Belajar dan Faktor-Faktor yang Mempengaruhinya. Jakarta: PT Rineka Cipta.

Van Brummelen, H. (2009). Berjalan dengan Tuhan di dalam kelas: Pendekatan Kristiani untuk Pembelajaran. Jakarta: Universitas Pelita Harapan.

Widyastuti, E. (2015). Peningkatan Kemampuan Pemahaman Konsep dan Komunikasi Matematis Siswa dengan Menggunakan Pembelajaran Kooperatif Tipe Jigsaw. Journal mathematics education, I(1), 50-64. 